\title{
Implementasi AJAX pada Peta Wisata "esbatu" Sistem Informasi Jejaring Wisata Kota Batu
}

\author{
Agung Panji Sasmito1,*, Hani Zulfia Zahro’2, Rofila El Maghfiroh³ \\ 1,2,3 Jurusan Teknik Informatika S-1 Institut Teknologi Nasional (ITN) Malang \\ (corresponding author) agungpanjisasmito@lecturer.itn.ac.id*)
}

\begin{abstract}
The lack of tourism information in Batu city which could be accessed online and integrated has made Batu's tourism potential was less soon known by domestic and foreign travelers. So far the tourism information in Batu was merely on printed media and electronic media, and not yet information which spreaded through the internet like online tourism map. This research is aimed to develop tourism map with AJAX on "esbatu" tourism networking information system of Batu City. The study is Research and Development study which held on Tourism and Culture Office of Batu City. The development was held by waterfall model with BlackBox testing. The IS validity is measured by DeLone and McLean Model of Information Systems Success. The result of BlackBox testing refer if tourism map of "esbatu" tourism networkings' fungsionalities are working well. The result of validity from IS expert, Batu's tourism expert, and some prospective users were "esbatu"'s IS segment and tourism information are very valid and suitable to use without any revision.
\end{abstract}

Keyword- tourism map, tourism networking, information system.

Intisari- Minimnya informasi terkait kepariwisataan di Kota Batu yang bisa diakses online dan terintegrasi membuat potensi pariwisata di Batu kurang begitu dikenal oleh wisatawan domestik maupun mancanegara. Sejauh ini informasi wisata di Kota Batu baru sebatas media cetak dan media elektronik, dan belum ada penyebaran informasi melalui internet seperti peta wisata yang dapat diakses secara online. Tujuan penelitian adalah mengembangkan peta wisata berbasis AJAX pada "esbatu" sistem informasi jejaring wisata Kota Batu. Rancangan penelitian adalah penelitian pengembangan yang dilakukan pada Dinas Pariwisata dan Kebudayaan Kota Batu. Pengembangan dilaksanakan dengan menggunakan waterfall model dengan pengujian BlackBox testing. Validitas peta wisata diukur dengan menggunakan DeLone and McLean Model of Information Systems Success. Hasil pengujian dengan BlackBox testing menunjukkan bahwa secara fungsionalitas semua fitur pada peta wisata berjalan lancar. Hasil validasi kepada ahli sistem informasi, ahli pariwisata Kota Batu, dan beberapa calon pengguna peta wisata pada sistem informasi "esbatu" menunjukkan bahwa peta wisata sangat valid dari segi sistem informasi dan informasi pariwisata sehingga layak digunakan tanpa revisi.

Kata Kunci- peta wisata, jejaring wisata, sistem informasi

I. PENDAHULUAN

Indonesia merupakan negara yang kaya akan daerah pariwisata. Secara harfiah, melalui pariwisata perekonomian pada daerah tersebut dapat ditingkatkan [1] - [4]. Pariwisata adalah salah satu bagian dari infrastruktur dari perkembangan ekonomi [5], karena pariwisata dapat meningkatkan pertumbuhan ekonomi baik secara langsung maupun tidak langsung, yaitu dengan merangsang pertumbuhan sektor lain maupun meningkatkan pendapatan domestik dan permintaan efektif [3]. Dengan demikian, pariwisata merupakan salah satu komoditas yang dapat diunggulkan oleh Indonesia untuk memajukan perekonomian.

Sayangnya, pengelolaan pariwisata di Indonesia masih kurang optimal dan merata. Wisatawan lokal maupun mancanegara mayoritas hanya mengetahui daerah-daerah pariwisata Indonesia yang terkenal saja, seperti Yogyakarta dan Bali. Padahal masih banyak daerah lain yang memiliki daya tarik wisata namun belum seterkenal Yogyakarta maupun Bali. Contohnya adalah Kota Batu dengan pertumbuhan pariwisata yang makin berkembang pesat dalam kurun 2004 hingga tahun 2013 [4]

Kota Batu identik dengan industri pariwisata sebagai komoditas utama [6]. Bagi pariwisata, tidak terkecuali pariwisata di Kota Batu, pengunjung merupakan salah satu faktor yang penting karena kepuasan pengunjung merupakan salah satu tolak ukur service quality dari objek wisata [7]. Oleh karena itu, diperlukan hubungan yang terbina baik antara pariwisata dengan pengunjung. Untuk menjadi sebuah objek wisata yang menarik minat pengunjung, objek wisata harus pandai mempelajari keinginan pengunjung, sehingga diharapkan objek wisata dapat mengambil langkah-langkah yang tepat untuk meningkatkan pelayanan kepada pengunjung yang diharapkan dapat meningkatkan pendapatan perusahaan. 
Salah satu pelayanan yang dapat senantiasa ditingkatkan adalah dengan penyediaan informasi yang cepat, akurat, dan memiliki jangkauan yang luas.

Minimnya informasi terkait kepariwisataan di Kota Batu yang bisa diakses online dan terintegrasi membuat potensi pariwisata di Batu kurang begitu dikenal oleh wisatawan domestik maupun mancanegara, termasuk aspek promosi. Padahal, promosi dilakukan sebagai usaha untuk memperbesar daya tarik objek wisata serta menginformasikan atau memberitahukan objek-objek dan atraksi wisata yang ada [8]. Informasi pariwisata dapat berguna untuk promosi [9]. Sejauh ini, promosi dan penyebarluasan wisata secara umum dilaksanakan melalui media tercetak, televisi, dan radio sesuai dengan tingkatan pengguna komunikasi tertentu [5]. Berdasarkan wawancara kepada Setyo Adji selaku Kabid Pengembangan SDM Pariwisata Dinas Pariwisata dan Kebudayaan Kota Batu diperoleh fakta bahwa penyebaran informasi wisata yang valid di Kota Batu baru sebatas penyebaran melalui brosur, papan reklame, baliho, dan sedikit yang menggunakan media elektronik seperti televisi dan radio. Bahkan, hanya sedikit objek wisata yang menyebarkan informasi pariwisata melalui internet, seperti yang dituturkan oleh Anggraheni Intan Sari, S.S.T., Par. selaku staf Pusat Informasi Pariwisata Kota Batu. Wawancara selanjutnya kepada Famila Yanateha, S.T. selaku Pelaksana Umum Promosi dan Pemasaran Produk Wisata Dinas Pariwisata dan Kebudayaan Kota Batu diketahui bahwa sejauh ini belum ada informasi terkait objek wisata ter-mapping yang dapat diakses secara online, seperti peta wisata berbasis online. Setidaknya, peta wisata dengan fitur: (1) informasi lokasi atau titik koordinat pada peta; (2) informasi dasar wisata seperti informasi umum, biaya tiket masuk, dan jam operasional objek wisata; dan (3) foto atau ilustriasi objek wisata diperlukan untuk penyebaran informasi objek wisata. Sejauh ini, informasi objek wisata baru sebatas peta wisata pada: (1) handbook Pesona Wisata Kota Batu yang dapat diperoleh secara hard copy di Pusat Informasi Pariwisata; serta (2) peta wisata Kota Batu pada baliho di beberapa titik Kota Batu. Padahal, penyebaran informasi pariwisata dan promosi objek wisata tidak cukup hanya melalui media cetak (seperti koran, majalah, atau brosur) maupun media elektronik (seperti televisi dan radio) saja.

Seiring berkembangnya teknologi informasi, penyebaran informasi wisata dimungkinkan melalui internet, karena penyebaran informasi wisata melalui internet dapat meningkatkan citra objek wisata [9]. Selain penyebaran informasi, promosi wisata dapat dilakukan secara sukses melalui internet [10], karena promosi wisata melalui internet dapat berkontribusi positif terhadap pariwisata [11]. Salah satu teknologi yang sedang berkembang dewasa ini adalah teknologi sistem informasi berbasis web yang dapat diakses kapan saja dan di mana saja, selama terdapat perangkat dengan browser web dan koneksi jaringan internet. Tren web programming yang sedang berkembang saat ini adalah Asynchronous JavaScript and XML (AJAX). AJAX merupakan salah satu teknologi dalam teknik pemrograman web yang dapat membuat halaman web menjadi interaktif [12]. AJAX bermanfaat dalam membuat halaman web lebih responsif dengan bertukar sejumlah kecil data dengan server di belakang layar, sehingga seluruh halaman web tidak harus reload setiap kali pengguna meminta perubahan [13] atau hanya membutuhkan waktu tunggu yang sedikit [14]. Dengan demikian, dengan mengimplementasikan AJAX akan membuat halaman web lebih interaktif, responsif, dan tanpa harus me-refresh browser web.

Berdasarkan hal tersebut, tergagas ide berupa pengembangan peta wisata Kota Batu dengan mengimplementasikan teknologi AJAX. Peta wisata Kota Batu akan diimplementasikan dalam "esbatu", yaitu sistem informasi jejaring wisata Kota Batu yang diharapkan dapat menjadi sebuah sarana berbagi informasi dan promosi wisata di Kota Batu yang bisa diakses online dan terintegrasi.

\section{KAJIAN PUSTAKA}

\section{A. Sistem Informasi Berbasis Web dan AJAX}

Sistem informasi merupakan sebuah sistem yang menerima sumber daya data sebagai input dan proses menjadi produk informasi sebagai output [15]. Definisi lain terkait sistem informasi adalah sekelompok komponen yang berinteraksi untuk menghasilkan informasi. Lima komponen dari sistem informasi adalah perangkat keras, perangkat lunak, data, prosedur, dan orang-orang [16].

Menurut Parker dan Case [17] menjelaskan bahwa sistem informasi adalah sekelompok elemen atau bagian yang terintegrasi dan terkoordinasi untuk mencapai sebuah tujuan. Komponen-komponen yang berhubungan akan mengumpulkan (input), memanipulasi (proses), dan mendiseminasikan (output) data dan informasi, serta menyediakan feedback untuk mencapai sebuah tujuan [17]. Dengan kata lain, sistem informasi adalah kumpulan komponen yang saling berinteraksi dan umumnya berbasis teknologi informasi dan bekerja bersama-sama guna menghasilkan informasi yang diperlukan oleh organisasi untuk mencapai tujuannya.

Terdapat berbagai bentuk sistem informasi, diantaranya adalah sistem informasi berbasis web. Sistem informasi berbasis web adalah sistem informasi yang dapat diakses melalui World Wide Web [18]. Dewasa ini, sistem informasi berbasis web berkembang seiring perkembangan pemrograman web dan tren-tren baru, seperti penggunaan PHP, CSS, JavaScript, hingga AJAX. 
AJAX merupakan teknologi dalam pemrograman web yang dapat menginteraktifkan sebuah halaman web [13]. AJAX dapat membuat halaman web lebih responsif dengan bertukar sejumlah kecil data dengan server di belakang layar, sehingga seluruh halaman web tidak harus reload setiap kali pengguna meminta perubahan [12] atau hanya membutuhkan waktu tunggu yang sedikit [14].

\section{B. Model Proses Waterfall}

Waterfall model merupakan salah satu model proses perangkat lunak yang mengambil kegiatan proses dasar seperti spesifikasi, pengembangan, validasi dan evolusi dengan mempresentasikannya sebagai fase-fase proses yang berbeda seperti analisis dan definisi persyaratan, perancangan perangkat lunak, implementasi dan pengujian unit, integrasi dan pengujian sistem, operasi dan pemeliharaan [19]. Waterfall model lebih cocok untuk perangkat lunak dengan spesifikasispesifikasi kebutuhan telah teridentifikasi dengan baik [20]. Alur waterfall model ditunjukkan pada Gambar 1.



Gambar 1 Waterfall Model [19]

III. Metode

Peta wisata akan dikembangkan dengan menerapkan waterfall model. Pemilihan waterfall model dalam pengembangan peta wisata Kota Batu didasarkan oleh pertimbangan bahwa kebutuhan sistem sudah dijelaskan pada awal pengembangan, yaitu telah direncanakannya peta wisata dengan fitur tertentu. Fitur-fitur tersebut antara lain: (1) informasi lokasi atau titik koordinat pada peta; (2) informasi dasar wisata seperti informasi umum, biaya tiket masuk, dan jam operasional objek wisata; dan (3) foto atau ilustriasi objek wisata. Selain itu, diperlukan user interface yang memungkinkan admin untuk melakukan penambahan, pengubahan, dan penghapusan objek wisata. User interface untuk pengguna harus dapat menerima respon klik oleh pengguna pada peta wisata yang akan menampilkan informasi dasar wisata dan foto atau ilustrasi objek wisata.

Terdapat 5 tahap dalam waterfall model, yaitu: (1) requirements analysis and definition; (2) system and software design; (3) implementation and unit testing; (4) integration and system testing; dan (5) operation and maintenance [19] [20]. Skema alur waterfall model yang telah dioperasionalkan sesuai dengan kebutuhan penelitian ditampilkan pada Gambar 2.
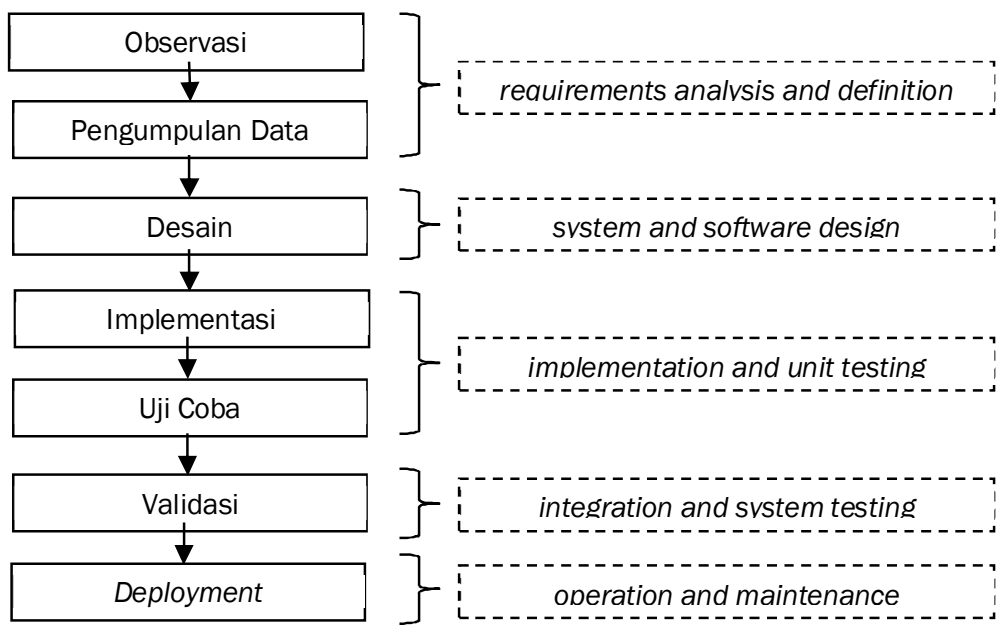

Gambar 2 Waterfall Model dengan Operasionalitas Langkah-Langkah 


\section{A. Observasi}

Observasi dilaksanakan dengan melakukan identifikasi masalah di Kota Batu terkait masalah kurangnya informasi dan promosi wisata di Kota Batu, terutama dari segi ketersediaan peta wisata Kota Batu. Observasi dilaksanakan dengan metode: (a) dokumentasi pada berita mutakhir dan hasil penelitian terbaru terkait kepariwisataan di Kota Batu; dan (2) wawancara kepada beberapa masyarakat dan pihak dari Dinas Pariwisata dan Kebudayaan Kota Batu terkait informasi kepariwisataan di Kota Batu yang bisa diakses online, terintegrasi, dan up-to-date. Berdasarkan observasi ditemukan permasalahan yaitu minimnya informasi kepariwisataan di Kota Batu yang bisa diakses online, terintegrasi, dan up-todate, termasuk belum adanya peta wisata yang berbasis online. Solusi yang diberikan sebagai salah satu alternatif pemecahan masalah adalah berupa inovasi pengembangan peta wisata Kota Batu dengan mengimplementasikan AJAX.

\section{B. Pengumpulan Data}

Pengumpulan data yang relevan dilaksanakan dalam upaya mengembangkan content dasar dari sistem informasi jejaring wisata Kota Batu dengan melakukan pendataan terhadap informasi dan sebaran objek wisata di Kota Batu. Pemerolehan informasi dan potensi wisata dilakukan melalui observasi objek wisata Kota Batu dengan melibatkan Pusat Informasi Pariwisata di bawah Dinas Pariwisata dan Kebudayaan Kota Batu. Informasi yang diperoleh pada langkah ini akan divalidasi oleh Dinas Pariwisata dan Kebudayaan Kota Batu pada langkah keenam.

\section{Desain}

Langkah selanjutnya adalah pengembangan design peta wisata Kota Batu berbasis web dan mengimplementasikan AJAX yang dikembangkan dari [21]. Desain diagram konteks dan DFD level 1 dari peta wisata ditampilkan pada Gambar 3 dan 4.

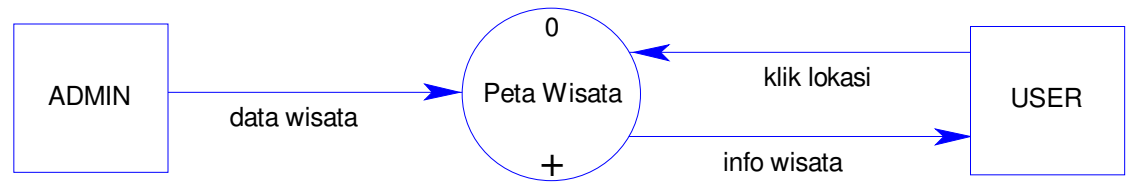

Gambar 3 Diagram Konteks Peta Wisata Kota Batu



Sketsa design tampilan peta wisata dibuat dan dipilih sebuah template yang mampu mencerminkan sebuah peta wisata dengan mempertimbangkan aspek Human and Computer Interaction. Layout peta wisata Kota Batu ditampilkan pada Gambar 5. 


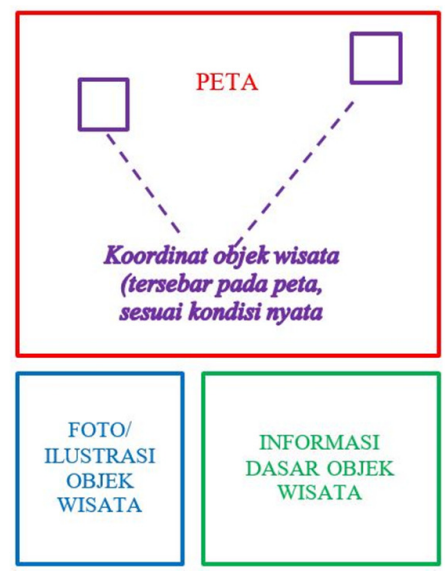

Gambar 5 Layout Peta Wisata Kota Batu

\section{Implementasi}

Setelah design layout dipilih, maka selanjutnya layout tersebut diimplementasikan ke dalam peta wisata. Peta wisata dikembangkan dengan menggunakan bahasa pemrograman HTML, PHP, CSS, dan AJAX. Tahap implementasi dilaksanakan mulai dari proses coding hingga pengisian content pada server lokal (localhost) XAMPP. Setelah pengisian content pada server lokal (localhost) XAMPP selesai dilaksanakan, maka langkah selanjutnya adalah implementasi peta wisata pada "esbatu" situs jejaring wisata Kota Batu dan di-hosting pada server milik Idwebhost (www.idwebhost.com) pada domain sewaan www.esbatu.net/petawisata.php.

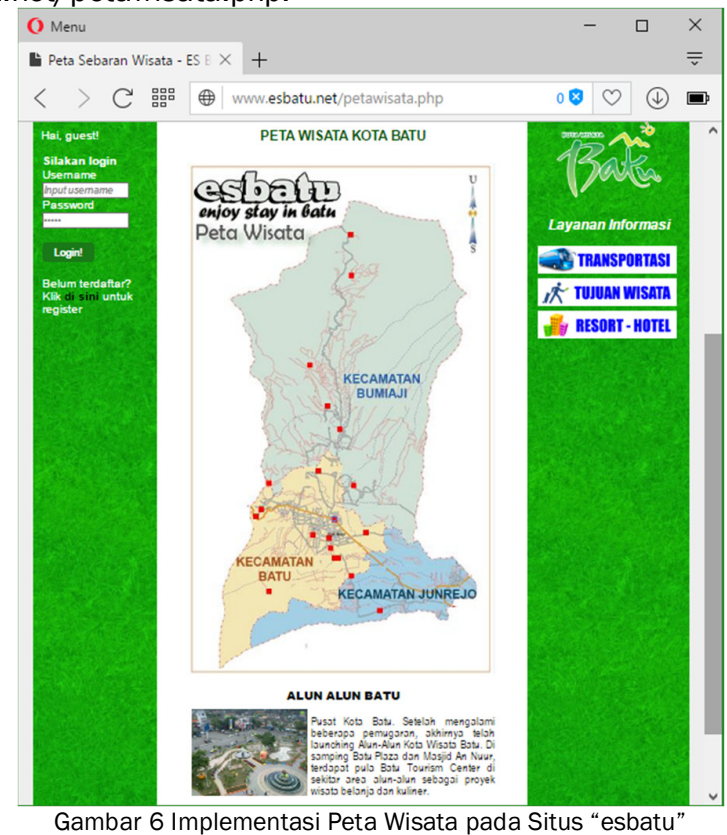

\section{E. Uji Coba}

Setelah peta wisata diimplementasikan pada situs "esbatu", maka tahap uji coba dilaksanakan. Uji coba dilaksanakan untuk mencari kesalahan atau kerusakan dari website dengan menggunakan metode blackbox testing. Dari hasil uji coba blackbox testing akan diketahui fitur-fitur yang belum sempurna atau belum berjalan dengan baik.

Pengujian blackbox testing dilaksanakan untuk menguji kesuksesan fitur-fitur pada "esbatu" meliputi: (a) penambahan objek wisata; (b) pengubahan objek wisata; (c) penghapusan objek wisata; dan (d) penerimaan respon klik oleh user pada peta wisata. Hasil pengujian blackbox testing yang telah dilaksanakan menunjukkan bahwa seluruh respon keluaran menghasilkan hasil yang diharapkan. Dengan kata lain, secara fungsionalitas seluruh fitur pada peta wisata berjalan dengan baik. 


\section{F. Validasi}

Setelah diuji coba, peta wisata akan divalidasi oleh: (a) ahli sistem informasi, dengan validator adalah: (1) Harditya Rahmat Ramadhan, S.Kom; dan (2) Alif Akbar Fitrawan, S.Pd., M.Kom; (b) ahli kepariwisataan, dengan validator adalah ahli wisata Kota Batu dari Dinas Pariwisata dan Kebudayaan Kota Batu, yaitu: (1) Taufik Fiantoko, A.Md; dan (2) Famila Yanateha, S.T., dan (c) beberapa calon pengguna, dilangsungkan pada tanggal 8 November 2016 dengan bantuan beberapa pegawai Pusat Informasi Pariwisata Kota Batu. Validasi tersebut bermaksud untuk: (1) mengetahui kelemahan dan kelebihan peta wisata dari segi TIK terutama dari segi sistem informasi; (2) validasi isi peta wisata, terutama informasi wisata yang disajikan; dan (3) menerima saran dan kritik dari calon pengguna peta wisata. Kriteria validasi diperoleh dari DeLone and McLean Model of Information Systems Success [22] yang meliputi: (1) systems quality; (2) information quality; (3) service quality; (4) use; (5) user satisfaction; dan (6) net benefits.

Pengolahan validitas yang diperoleh dari validator dapat menggunakan rumus presentase [23] sebagai berikut:

$$
v=\frac{\sum T S E V}{\sum S-\max } x 100 \%
$$

Keterangan:

$\mathrm{V} \quad=$ validitas

TSEV $=$ total skor empirik validator dalam seluruh butir soal

S-max = skor maksimal yang diharapkan dalam seluruh butir soal

Interpretasi data nilai yang didapat dari validator dikonversikan ke dalam bentuk persentase sehingga dapat dilihat kelayakan produk pengembangan. Kriteria kualifikasi penilaian yang diadaptasi dari Sa'dun dan Sriwijaya [23] ditunjukkan Tabel 1.

Tabel 1 Kriteria Validasi [23]

\begin{tabular}{|c|c|c|}
\hline Persentase (\%) & Tingkat Kelayakan & Keterangan \\
\hline $75-100$ & Sangat valid & Dapat digunakan tanpa direvisi \\
\hline $50-75$ & Cukup valid & Dapat digunakan dengan revisi kecil \\
\hline $25-50$ & Tidak valid & Tidak dapat digunakan \\
\hline$<25$ & Sangat tidak valid & Terlarang digunakan \\
\hline
\end{tabular}

\section{G. Deployment}

Peta wisata Kota Batu yang terintegrasi pada situs "esbatu" sistem informasi jejaring wisata Kota Batu adalah produk akhir dari seluruh rangkaian pelaksanaan program yang siap digunakan sebagai sarana berbagi informasi wisata di Kota Batu. Peta wisata ini pun siap disebarkan dan diluncurkan agar dapat berfungsi sebagaimana mestinya.

\section{HASIL DAN PEMBAHASAN}

Hasil ujicoba dengan BlackBox Testing ditampilkan pada Tabel 2.

Tabel 2 Hasil BlackBox Testing

\begin{tabular}{|c|c|c|c|}
\hline No. & Fitur & Hasil & Hasil \\
\hline 1. & penambahan objek wisata & $\begin{array}{l}\text { Dapat menambahkan objek wisata dengan koordinat yang } \\
\text { tepat, informasi sesuai dengan inputan admin, dan foto } \\
\text { sesuai dengan yang diunggah admin }\end{array}$ & $\begin{array}{l}{[\sqrt{ }] \text { diterima }} \\
{[\text { ]ditolak }}\end{array}$ \\
\hline 2. & pengubahan objek wisata & $\begin{array}{l}\text { Dapat mengubah objek wisata dengan koordinat yang } \\
\text { tepat, informasi sesuai dengan ubahan admin, dan foto } \\
\text { sesuai dengan yang diunggah admin }\end{array}$ & $\begin{array}{l}{[\sqrt{ }] \text { diterima }} \\
{[\text { ]ditolak }}\end{array}$ \\
\hline 3. & penghapusan objek wisata & $\begin{array}{l}\text { Dapat menghapus objek wisata dan titik koordinat pada } \\
\text { peta menghilang }\end{array}$ & $\begin{array}{l}{[\sqrt{ }] \text { diterima }} \\
{[\text { ]ditolak }}\end{array}$ \\
\hline 4. & $\begin{array}{l}\text { penerimaan respon klik oleh } \\
\text { user pada peta wisata }\end{array}$ & $\begin{array}{l}\text { Dapat menampilkan informasi wisata dan foto objek wisata } \\
\text { tanpa perlu me-refresh halaman }\end{array}$ & $\begin{array}{l}{[\sqrt{ }] \text { diterima }} \\
\text { [ ]ditolak }\end{array}$ \\
\hline
\end{tabular}

Hasil pengujian BlackBox testing menunjukkan bahwa secara fungsionalitas situs jejaring wisata "esbatu" berjalan lancar seluruhnya dan seluruh fitur pada "esbatu" berjalan dengan baik.

Hasil validasi kepada ahli sistem informasi, ahli pariwisata Kota Batu, serta beberapa pengguna masing-masing ditampilkan pada Tabel 3, Tabel 4, dan Tabel 5. 
Tabel 3 Hasil Validasi Kepada Ahli Sistem Informasi

\begin{tabular}{|l|l|c|c|c|c|}
\hline \multicolumn{1}{|c|}{ No. } & \multicolumn{1}{|c|}{ Kriteria } & TSEV & S-max & \% & Validitas \\
\hline 1. & systems quality & 172 & 176 & 97,73 & Sangat valid \\
\hline 2. & information quality & 29 & 32 & 90,63 & Sangat valid \\
\hline 3. & service quality & 20 & 24 & 83,33 & Sangat valid \\
\hline 4. & Use & 44 & 48 & 91,67 & Sangat valid \\
\hline 5. & user satisfaction & 40 & 48 & 83,33 & Sangat valid \\
\hline 6. & net benefits & 21 & 24 & 87,50 & Sangat valid \\
\hline & Validitas & $\mathbf{3 2 6}$ & $\mathbf{3 5 2}$ & $\mathbf{9 2 , 6 1}$ & Sangat valid \\
\hline
\end{tabular}

Tabel 4 Hasil Validasi Kepada Ahli Pariwisata Kota Batu

\begin{tabular}{|l|l|c|c|c|c|}
\hline \multicolumn{1}{|c|}{ No. } & \multicolumn{1}{|c|}{ Kriteria } & TSEV & S-max & \% & Validitas \\
\hline 1. & systems quality & 38 & 48 & 79,17 & Sangat valid \\
\hline 2. & information quality & 71 & 88 & 80,68 & Sangat valid \\
\hline 3. & service quality & 35 & 40 & 87,50 & Sangat valid \\
\hline 4. & use & 31 & 40 & 77,50 & Sangat valid \\
\hline 5. & user satisfaction & 38 & 48 & 79,17 & Sangat valid \\
\hline 6. & net benefits & 20 & 24 & 83,33 & Sangat valid \\
\hline & Validitas & $\mathbf{2 3 3}$ & $\mathbf{2 8 8}$ & $\mathbf{8 0 , 9 0}$ & Sangat valid \\
\hline
\end{tabular}

\begin{tabular}{|l|l|c|c|c|l|}
\hline \multicolumn{1}{|c|}{ Kriteria } & \multicolumn{1}{|c|}{ Tabel 5 Hasil Validasi Kepada Pengguna } \\
\hline No. & \multicolumn{1}{|c|}{ TSEV } & S-max & $\%$ & Validitas \\
\hline 1. & systems quality & 181 & 240 & 75,41 & Sangat valid \\
\hline 2. & information quality & 101 & 144 & 76,39 & Sangat valid \\
\hline 3. & service quality & 148 & 192 & 77,08 & Sangat valid \\
\hline 4. & use & 224 & 288 & 77,78 & Sangat valid \\
\hline 5. & user satisfaction & 193 & 240 & 80,41 & Sangat valid \\
\hline 6. & net benefits & 114 & 144 & 79,17 & Sangat valid \\
\hline & Validitas & 961 & $\mathbf{1 2 4 8}$ & $\mathbf{7 7 , 0 0}$ & Sangat valid \\
\hline
\end{tabular}

Hasil validasi menunjukkan bahwa peta wisata sangat valid dari segi sistem informasi. Hasil validasi menunjukkan bahwa informasi wisata yang ditampilkan pada peta wisata sangat valid. Merujuk kepada hasil tersebut, dapat disimpulkan bahwa peta wisata layak digunakan tanpa revisi.

\section{Penutup}

\section{A. Kesimpulan}

Kesimpulan dari penelitian ini adalah:

1) Untuk merancang peta wisata dengan mengimplementasikan AJAX pada sistem informasi jejaring wisata Kota Batu dapat digunakan waterfall model yang meliputi (a) requirements analysis and definition; (b) system and software design; (c) implementation and unit testing; (d) integration and system testing; dan (e) operation and maintenance.

2) Hasil pengujian dengan BlackBox testing menunjukkan bahwa secara fungsionalitas peta wisata berbasis AJAX pada jejaring wisata "esbatu" berjalan lancar.

3) Hasil validasi kepada ahli sistem informasi menunjukkan bahwa peta wisata berbasis AJAX pada "esbatu" sangat valid dari segi sistem informasi dan informasi pariwisata sehingga layak digunakan tanpa revisi.

\section{B. Saran}

Rekomendasi untuk kegiatan penelitian pengabdian masyarakat selanjutnya adalah: (1) mengembangkan peta sebaran informasi hotel dan resort pada jejaring wisata Kota Batu; (2) senantiasa meng-update informasi wisata di Kota Batu sebaga konten dari peta wisata, sehingga diperlukan komunikasi yang baik antara pengembang peta wisata, Dinas Pariwisata dan Kebudayaan Kota Batu, serta objek wisata; dan (3) meluaskan objek penelitian menjadi tingkat Malang Raya atau tingkat yang lebih luas. 


\section{UCAPAN TERIMA KASIH}

Penelitian ini merupakan bagian dari penelitian pengabdian kepada masyarakat yang didanai oleh Institut Teknologi Nasional (ITN) Malang. Ucapan terima kasih penulis sampaikan kepada: (1) validator ahli bidang sistem informasi, yaitu: (a) Harditya Rahmat Ramadhan, S.Kom; dan (b) Alif Akbar Fitrawan, S.Pd., M.Kom; (2) validator ahli kepariwisataan Kota Batu dari Dinas Pariwisata dan Kebudayaan Kota Batu, yaitu: (a) Taufik Fiantoko, A.Md; dan (b) Famila Yanateha, S.T., (3) Pusat Informasi Pariwisata Kota Batu; dan (4) Bapak Setyo Adji selaku Kabid Pengembangan SDM Pariwisata Dinas Pariwisata dan Kebudayaan Kota Batu. Ucapan terima kasih juga penulis sampaikan kepada Lembaga Penelitian dan Pengabdian kepada Masyarakat (LPPM) Institut Teknologi Nasional (ITN) Malang.

\section{REFERENSI}

[1] Bankole, Abiodun. 2002. The Nigerian Tourism Sector: Economic Contribution, Constraints, and Opportunities. Journal of Hospitality Financial Management, 10(7): 71-89.

[2] Ardahaey, Fateme Tohidy. 2011. Economic Impacts of Tourism Industry. International Journal of Business and Management, 6(8): $206-215$.

[3] Gökovali, Ummuhan dan Ozan Bahar. 2006. Contribution of Tourism to Economic Growth: A Panel Data Approach. Anatolia: An International Journal of Tourism and Hospitality Research, 17(2): 5-13

[4] Septiyastuti, Luvi dkk. 2014. Building New Tourist Attraction: Job Creation of Job Destrution. Prosiding Seminar Internasional SOCIOINT14 (International Conference on Social Sciences and Humanitie), Istanbul, 8-10 September 2014.

[5] Salehi, Hassan dan Morteza Farahbakhsh. 2014. Tourism Advertisement Management and Efective Tools in Tourism Industry. International Journal of Geography and Geology, 3(10): 124-134.

[6] JawaPos. 16 Februari 2015. Walikota Batu Eddy Rumpoko Sulap Kota Batu menjadi Ikon Wisata Jatim, (Online), (http://www.jawapos.com/baca/artikel/12977/Wali-Kota-Batu-Eddy-Rumpoko-Sulap-Kota-Batu-Menjadi-Ikon-Wisata-Jatim), diakses 27 Desember 2015

[7] Al-Ababneh, Mukhles. 2013. Service Quality and its Impact on Tourist Satisfaction. Interdisciplinary Journal Of Contemporary Research In Business, 4(12): 164-177.

[8] Yonathan, Moses. 2012. Peranan Dinas Pariwisata dan Kebudayaan Kota Batu dalam Kegiatan Promosi Pariwisata Kota Batu. Artikel penelitian. Malang: Universitas Brawijaya.

[9] Molina, A, dkk.. 2010. Tourism Marketing Information and Destination Image Management. African Journal of Business Management, 4(5):722728.

[10] Alkharabsheh K.S, dkk. 2011. The Impact of Viral Marketing via Internet on Promotion of Tourism Products in Jordan. International Research Journal of Finance and Economics, 80(13): 138-147.

[11] Lai, Wen-Hsiang and Nguyen Quang Vinh. 2013. Online Promotion and Its Influence on Destination Awareness and Loyalty in the Tourism Industry. Advances in Management \& Applied Economics, 3(3): 15-30.

[12] Singh, Bhupendra dan Shashank Sahu. 2014. A Model for Performance Testing of Ajax Based Web Applications. International Journal of Research in Engineering and Technology, 3(4): 889-893.

[13] Kumar, S. Rajesh dan R. Aravazhi. 2013. A Study on Ajax in Web Applications with Latest Trends. International Journal on Recent and Innovation Trends in Computing and Communication, 1(6): 563-568.

[14] Kachhwaha, Rajendra dan Priyadarshi Patni. 2012. Ajax Enabled Web Application Model with Comet Programming. International Journal of Engineering and Technology, 2(7): 1155-1161.

[15] O'Brien, J.A. 2003. Introduction to Information Systems: Essentials for the e-Business Enterprise, Boston: McGraw Hill-Irwin.

[16] Kroenke, D.M. 2008 Experiencing MIS, Ney Jersey: Pearson Prentice Hall.

[17] Parker, C. dan Case, T. 2003. Principles of Information System (8th Ed). New York: Prentice Hall.

[18] Schewe, Klaus-Dieter dan Bernard Thalheim. 2010. Web Information System Portfolios: A Contribution to Pragmatics. Makalah disajikan pada 6th International Conference WEIBST di Valencia, Spanyol pada April 2010.

[19] Sommerville, lan. 2011. Software Engineering. Massachusetts: Addison-Wesley.

[20] Pressman, Roger S. 2012. Rekayasa Perangkat Lunak Buku 1. Yogyakarta: Penerbit Andi.

[21] Lisangan, Erick. 11 Mei 2010. Membuat GIS Peta Dunia Sederhana dengan PHP dan AJAX, (Online), (https://erick1719.wordpress.com/2010/05/11/membuat-gis-peta-dunia-sederhana-dengan-php-dan-ajax/), diakses 1 Februari 2016.

[22] DeLone, William H. dan Ephraim R. McLean. 2003. The DeLone and McLean Model of Information Systems Success: A Ten-Year Update. Journal of Management Information Systems, 19(4): 9-30.

[23] Sa'dun, Akbar dan Sriwijaya. 2012. Pengembangan Kurikulum dan Pembelajaran Ilmu Pengetahuan Sosial (IPS). Yogyakarta: Cipta Media. 